\title{
Need for implementation of pharmacoeconomics in healthcare system, case of analysis of antibiotic consumption in Republic of Macedonia for 2016
}

\author{
Stevche Acevski ${ }^{1 *}$ and Zoran Nakov ${ }^{2}$ \\ ${ }^{1}$ Alkaloid AD, blv. Aleksandar Makedonski No. 12, 1000 Skopje, Republic of Macedonia \\ ${ }^{2}$ Novo Nordisk Farma dooel, str. Nikola Kljusev No. 11, 1000 Skopje, \\ Republic of Macedonia
}

Received: March 2018; Accepted: June 2018

\begin{abstract}
Pharmacoeconomics is new and modern health science, implemented in developed societies, to play core role in creating health policies. The main aim of pharmacoeconomic analysis is development of science methodology for evaluation of costs and outcomes of treatment, evaluation of economic parameters in the face of outcomes of clinical results, from different treatment options. Pharmaceutical companies implemented pharmacoeconomic principles for diversifying marketing approach and market access in pharmaceutical development. New healthcare systems demand increased costs for medical care, pharmaceutical products and medical devices. Process of medical costs for evaluation of costs evolved, indirect and hidden costs are part of sole process of evaluation. Health authorities from one side and pharmaceutical companies from other side developed unique methodologies for evaluation. With these implemented changes, traditional concept for evaluation of efficacy and safety of medical devices and pharmaceutical products was overbridged and pharmacoeconomics is base for research, development, registration, reimbursement, as well as dispensing and follow the life cycle of medicines. Results from antibiotic consumption analysis in Republic of Macedonia at 2016 showed that total antibiotic consumption and antibiotic consumption per DDD/1000 citizens is according to average EU trends, mostly similarly to the usage trends of low-income countries. But usage of new and innovative antibiotic is on very low level, which indicates the need of further implementing of pharmacoeconomic analysis and principles in decision making process, for improved health care for the patients. The ultimate goal of implementing the pharmacoeconomic system in each country is enhancing the benefit to the patient through improved resource allocation.
\end{abstract}

Keywords: pharmacoeconomics, type of pharmacoeconomic analysis, antibiotic consumption, Republic of Macedonia

\section{Introduction}

Pharmacoeconomics research is the process of identifying, measuring, and comparing the costs, risks, and benefits of programs, services or therapies and determining which alternative produces the best health outcome for the resources invested (Drummond et al.,
1989). In general, pharmacoeconomic analysis correlates the cost of providing a medical service, using pharmaceutical product or medical device, with outcomes realized by using that specific product or service. This information can assist to clinical decision makers and health care policy makers in choosing the most costeffective treatment options. The aim of pharmacoeconomic analysis is to improve individual and public health, by making decisions and determining the

\footnotetext{
* stevce.acevski@gmail.com
} 
relative value of alternative treatment options (Hunink et al., 2014). In process of developing effective pharmacoeconomic methodology different strategies for collecting, evaluating and analyzing data are developed. Different sources for data inputs are developed, in order to get more wide and different perspective in produced costs. Randomized controlled clinical trials provide data on clinical drug efficacy and tolerability, with accent of reallife activities of the pharmaceutical products. Data from sick and data from healthy individuals are collected in controlled well designed studies, to contribute process of transparency of pharmacoeconomic analysis. High valued medicines (oncology, hematology drugs, drugs for cardiovascular diseases, diabetes etc.) are usually evaluated through pharmacoeconomic analysis. Medicines with high volume of consumption (antidepressants, antibiotics, NSAID, medicines for asthma and allergy treatment etc.) and also medicines for rare diseases (AIDS, immunosuppressant's, rare diseases) are also subject of pharmacoeconomic analysis (Kielhorn and Von der Schulenburg, 2000). Usually health insurance companies in developed countries use pharmacoeconomic analysis to evaluate variations in structure and volume of used medicines, with sole aim to improve and develop process of allocation of resources. Many issues regarding uncertainties which product should be used can be resolved with varieties of pharmacoeconomic analysis.

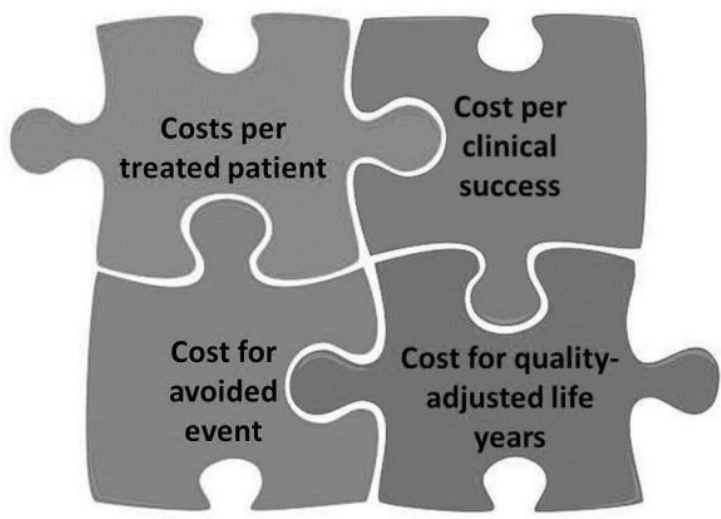

Fig. 1 Types of costs determined by pharmacoeconomic analysis.

Choosing which criteria to evaluate when using pharmaceutical products requires mix of economical, clinical and humanistic results of drug use (Normand, 1991). In pharmacoeconomic evaluations costs are always on the upper side of the fractional line, while clinical, economic and humanistic results of treatment are on the down side. Clinical results could be days of treatment, lower blood pressure, decreased neural strokes, avoided cardiovascular events, lowering cholesterol level, while economical outcomes would be a quantification of costs (medical or unmedical) that is avoided or reduced by an intervention (Hickey et al., 1996). The humanistic cost would be the quality of life, expected life extension or improvement patients' satisfaction. Following initial analysis of the data, next step is the calculation of the achieved clinical outcome (e.g. impaired cardiac events in the year) compared to different therapeutic approaches, in order to determine a value of paid expense (Cairns, 1996). Fig. 1. illustrates the different costs determined by pharmacoeconomic analysis.

With pharmacoeconomics different costs for clinical, medical, health, social and behavioral interventions can be integrated into a single figure that shows the value of the intervention and makes it comparable to others, in contrast to the usual approach that evaluates values of different therapeutic options. When creating guides for various medical treatments, different models of pharmacoeconomic evaluation can offer quantification of data on programs and services for best allocated resources. For example: guides for hypertension treatment must take account of percentage of finished treatment, replacement of therapy, amount of medicines used for successful clinical outcome and avoided cardiovascular events (acute myocardial infarct, stroke, chronic heart failure etc.). Political pressure on healthcare systems often requires redistribution of health budget from one to another health intervention, usually with evaluation for better outcome of the treatment. This approach often comes as a result of Cost-Minimization Analysis (CMA), which compares cost and outcomes of two therapeutic options. According to numerous international studies, a variety of savings could be made with different healthcare campaigns.

For example, typical smoking cessation strategy cost approximately 1200 UK pounds per life year saved and 22000 UK pounds per death averted (Ormea et al., 2000). Reducing blood pressure from $<140 / 90 \mathrm{~mm} \mathrm{Hg}$ to $<130 / 85 \mathrm{~mm} \mathrm{Hg}$ in a group of high-risk individuals would result in an increased life expectancy from 16.5 to 17.4 years, while total medical costs would decline by 1450 US dollar (Elliot W. 2003). Hypercholesterolemia interventions have cost-effectiveness ratio between 0 and 50000 US dollar generally savings (Sassi et al., 2009).

To allocate resources for the best treatment, the real benefit of the treatment should be evaluated. Important factors in pharmacoeconomic analysis are analysis of cost and outcome evaluates benefits of service and gained results. Outcomes should be reported in single parameter or with classical clinical outcome (e.g. year's life gained). Treatment should be beneficial according to cost if clinical results are better from non-treatment alternative. Compared with non-treatment, beneficial results of treatment in terms of outcomes should be over any harmful effects of the health outcome and most importantly, compared to the future best alternative, treatment should be the best use of resources.

The cost-efficacy analysis (CEA) calculates the ratio of the difference in the invested funds of two alternatives of health intervention and the difference in performance 
between the two different alternatives. When evaluating of different alternatives in the mathematical display, the difference in the costs of the healthy alternative is always a denominator and numerator is always a difference of health benefit for the patient. The number that represents a benefit for the patient could be years of saved lives, avoided adverse effects, days of treatment etc. The primary goal of CEA is to evaluate two different alternatives with the same outcome at the end, but the disadvantage is the fact that important aspects can be overlooked, like a quality of life, patient's satisfaction, disability period etc. Difference between cost-efficacy analysis (CEA) and cost-benefit analysis (CBA) is that final result in CEA is a non-monetary unit, while in CBA final result is interpreted as the monetary unit (euro, dollar etc.), while in the cost-utility analysis (CUA) final result is years of life gained.

Antimicrobials are one of the widest prescribed medicines, causing huge economical costs to the societies. Antibiotic usage has its own rise since inventing of penicillin and high peak try last 30 years, following positive trend of innovating new and wide spectrum antibiotics. Continuous antibiotic usage highlights the need of implementing of surveillance system of use, since it is main trigger for antibiotic resistance growth. Antibiotic resistance is global public health problem, there are many reports of described serious misuse of antibiotics and highlighting the need for rational antibiotic prescribing practice. Monitoring antimicrobial prescription and consumption behavior provides insights and tools needed to inform therapy decisions, to assess the public health consequences of antimicrobial misuse and to evaluate the impact of resistance containment interventions (WHO, Surveillance of antimicrobial use, www.who.int). The lack of information's has hindered rational discussions about desirable levels of consumption. Many factors must be considered in attempting to define best levels of consumption, including local prevalence, susceptibility patterns, antibiotic prescribing practices and philosophy of use. Comparison with other populations and countries, especially with similar ones, help to give context in all antibiotic consumption initiatives. The European Surveillance of Antimicrobial Consumption Program (ESAC) has demonstrated that monitoring antimicrobial use patterns and costs can prove the crucial factor driving political commitment to successful campaigns to contain resistance, especially when surveillance of use is enhanced by surveillance of resistance (European Surveillance of Antimicrobial Consumption Program (ESAC) www.ecdc.europa.eu). Many studies have been done to document drug use patterns and indicate rational or irrational prescribing, overprescribing and misuse of drugs, multi-drug prescribing and overuse of antibiotics. Improving drug use would have important financial and public health benefits. Commonly used interventions, such as essential drug list and standard treatment guidelines are rarely systematically evaluated; the most of intervention studies are focused on prescribers in a public health setting, without taking into consideration private health practitioners. More research on different types of strategies is needed to draw conclusions on the effectiveness of a specific intervention strategy, evaluating the influence on socio-cultural factors influencing the impact of drug use interventions, from different perspectives patient, payer, doctor etc. (Le Grand et al., 1999). Provision of reliable and comparable national antibiotic consumption data is a prerequisite for understanding the epidemiology of antibiotic resistance. Although most courses of antibiotics are consumed in the community, antibiotic use in hospitals is a major driver of the emergence of multidrug-resistant bacteria responsible for healthcare-associated infections.

In order to evaluate antibiotic consumption in Republic of Macedonia for 2016, we evaluate consumption according to the Annual Report for 2016 published by Health Insurance Fund (HIF) of Republic of Macedonia (www.fzo.org.mk). In Macedonia there are 1231 medicines on HIF "Positive List" for reimbursement of whom 174 containing antibiotic active ingredients. Since refreshment of list of reimbursed medicines is frozen process in the past 10 years, our goals were to evaluate if the active "positive list" of reimbursed medicines is in scope of antibiotic therapeutic trends and with global antibiotic usage. Sales of medicines are presented in units and by DDD and are compared with annual sales and consumption of antibiotics in EU countries. The analysis is made by the class of antibiotics, presenting results for antibiotics as penicillin class of antibiotics, cephalosporin's, macrolides, quinolones and other. Results are compared with consumption of antibiotics in EU countries, report for 2016 issued from European Center for Disease and Control, from Stockholm, Sweden, as Summary of the latest data on antibiotic consumption in the European Union, ESACNet surveillance data, November 2017.

The aim of this research is to establish foundation for future implementation of pharmacoeconomic principles in decision making process in health care system in Republic of Macedonia. It was demonstrated that classical statistical approach can produce contradicting results, which consequently can produce additional unnecessary costs to society. The approach suggested within this research highlight the need of the implementation of pharmacoeconomics, resulting in better allocation of resources with final goal improved patient health.

\section{Material and methods}

Daily defined dose (DDD) is the assumed average maintenance dose per day for a drug used for its main indication in adults. The DDD for the anti-infective agents are as a main rule based on the use in infections of 
moderate severity. However, some anti-infective agents are only used in severe infections and their DDD are assigned accordingly. The DDD assigned are based on daily treatment. The duration of the treatment periods is not taken into consideration. For anti-infective agents given in a high initially starting dose followed by a lower daily maintained dose, the DDD are based on the maintained dose if the total duration of the treatment course is more than one week. If, however the treatment course is 7 days or less the DDD are assigned according to the average daily dose, the total course dose divided by the number of treatment days (WHO Collaborating Centre for drug statistics methodology, 2018). DDD does not always reflect recommended or prescribed daily dose. Only one DDD is assigned per each ATC code and route of administration. DDD provide measurement independent of price, currencies, package size and strength enabling researchers to assess trends in drug consumption and to perform comparison between population groups. For medical products approved for children the dose recommendations will differ based on age and body weight. Prescribed daily dosage and indications in a pediatric population should be used if available and compared with the DDD values. If the pediatric subgroup is difficult to identify the general DDD should be used as a measuring tool for overall comparisons (WHO Collaborating Centre for drug statistics methodology, 2018).

Calculation of yearly rates is made as follows:

\section{Total amount of antibiotics in ATC category dispensed in year/Population $=$ DDD/inhabitants (year)}

$$
\begin{gathered}
\text { DDD/inhabitants (year) } \times 1000 / 365=D D D / 1000 \\
\text { inhabitants }(\text { days })
\end{gathered}
$$

\section{Results}

Use of oral antibiotic is very valuable and controversial question for every country, regarding antibiotic consumption, allocated resources and antibiotic awareness connected with antibiotic resistance. Higher antibiotic consumption is directly correlated with higher antibiotic resistance rates of bacteria, but lowering antibiotic consumption, does not lead to lower antibiotic resistance rate. For the outpatient treatment, in Republic of Macedonia, HIF spend around 4.905.000 Euro, for totally 1.887 .775 packs of oral antibiotics, at year 2016, which is $11.9 \%$ of total budget of HIF spend for medicines for outpatient treatment presented on Fig. 2.

Since "positive list for medicines" is outdated, we analyze the structure of used antibiotics in Macedonia, in 2016, by the therapeutic class of antibiotics, to see which patients requirements does it meets and get the following results: 820.203 packs or $43.3 \%$ oral penicillin's were used in $2016,445.821$ pack or $23.5 \%$ oral cephalosporins, 330.689 or $17.5 \%$ oral macrolide antibiotics, 225.673 packs or $11.9 \%$ quinolones and the rest of the used oral antibiotics were 71.817 packs which represent $3.8 \%$, of total used oral antibiotics for outpatient treatment, in Macedonia, presented in Fig. 3. Calculated by packs of usage per patient in year 2016 in Republic of Macedonia 2.76 packs per day, of antibiotic were used on every 1000 citizens.

In EU countries, according to Summary of the latest data on antibiotic consumption in the European Union, ESAC-Net surveillance data, 3.1 packs of oral antibiotic were used at 2016, and registered nor increasing nor decreasing trend, according to previous years. Of all countries, Denmark, Estonia, Finland and Sweden have a decreasing trend of use of an oral antibiotic, in previous

\section{Annual HIF Budget Antibiotic vs All Other Drugs}

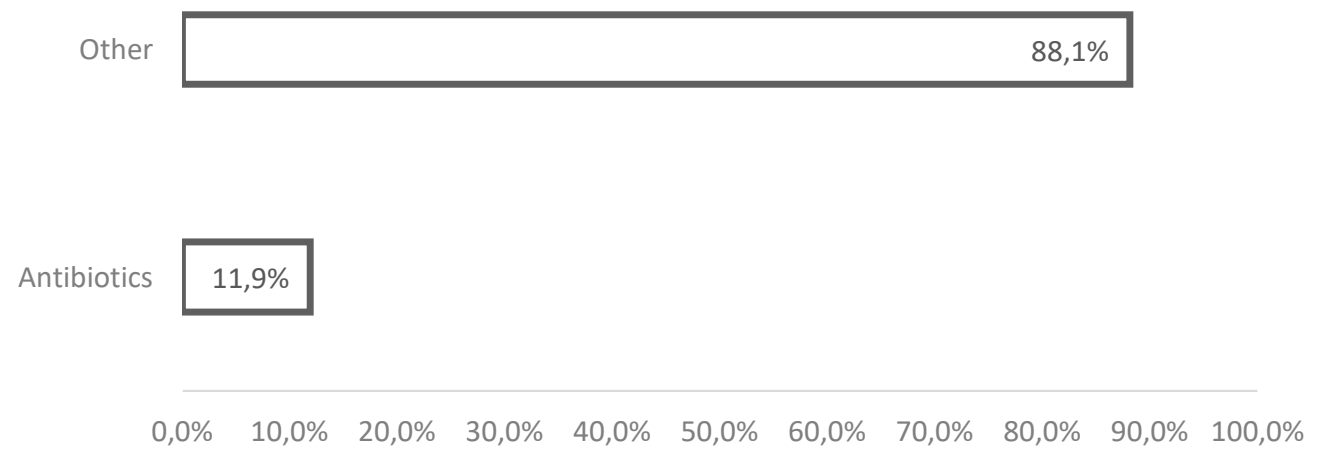

Fig. 2 Percentage of HIF budget spend for antibiotics in 2016 vs. budget spent for all other medicines, for outpatient treatment. 


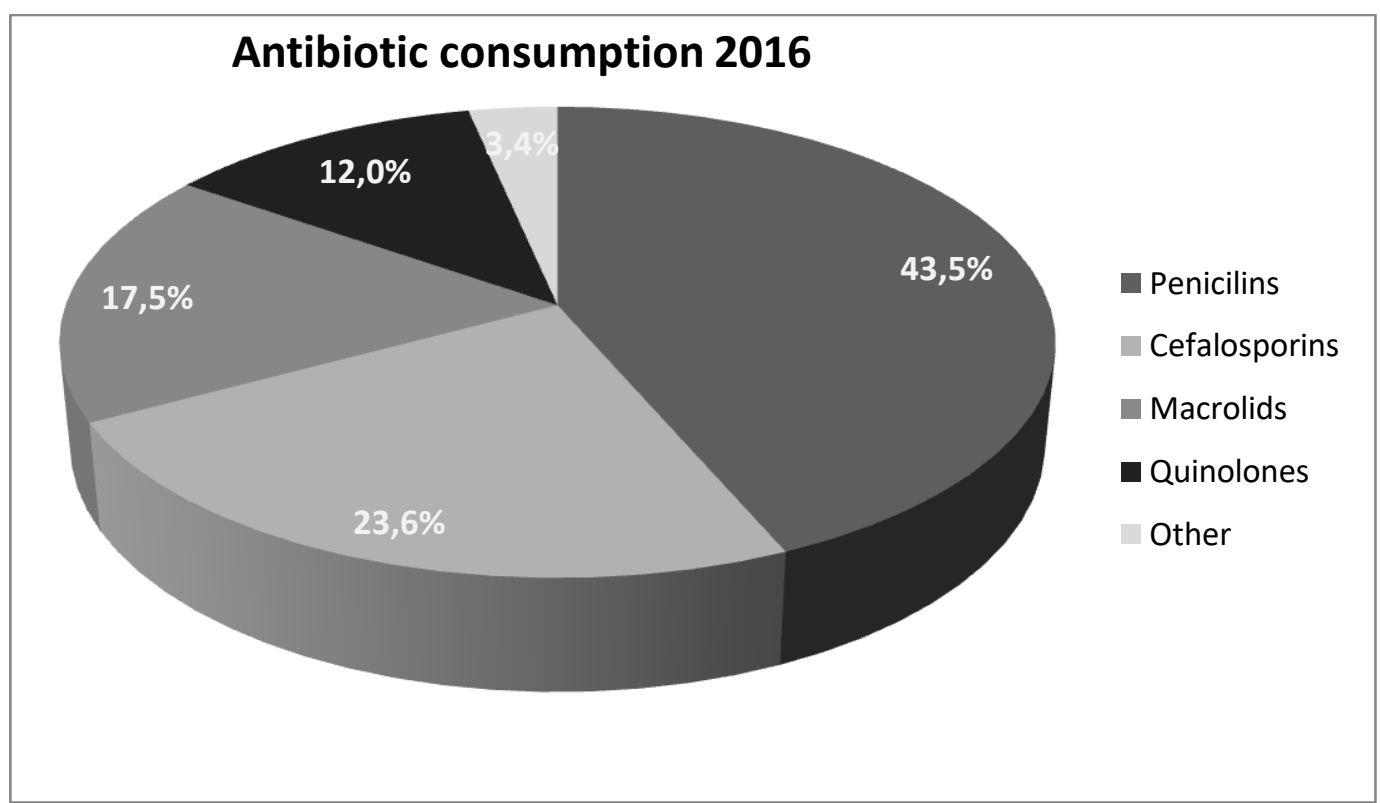

Fig. 3 Structure of antibiotic consumption by class at 2016 in Republic of Macedonia.

years. As indicated by European Centre for Disease Prevention and Control, for 2016 the range of use of oral antibiotic is 1.0 in Sweden to 4.7 in France packs per 1000 citizens per day (ECDC, 2017).

Calculated by DDD, and in accordance to the WHO DDD calculation guidelines, in Republic of Macedonia total 13.665.726 DDD of antibiotic was used in year 2016, or 7.3 DDD per citizen per day oral antibiotic. At 2016, for each 1000 inhabitants in Republic of Macedonia 20.01 DDD of antibiotic. In EU countries, according to Summary of the latest data on antibiotic consumption in the European Union, ESAC-Net surveillance data, use of oral antibiotic in a community is 21.9 DDD on 1000 citizens per day, even lower than the previous year, still without statistical significance (Fig. 4). Finland, Luxemburg, Norway, and Sweden showed decreasing trend in DDD antibiotic consumption, while Greece and Spain have increase trend for DDD antibiotic usage. For 2016, antibiotic use in EU countries was from 10.4 for Netherland to 36.3 for Greece DDD per 1000 citizens per day (ECDC, 2017).

The only official published data for annual

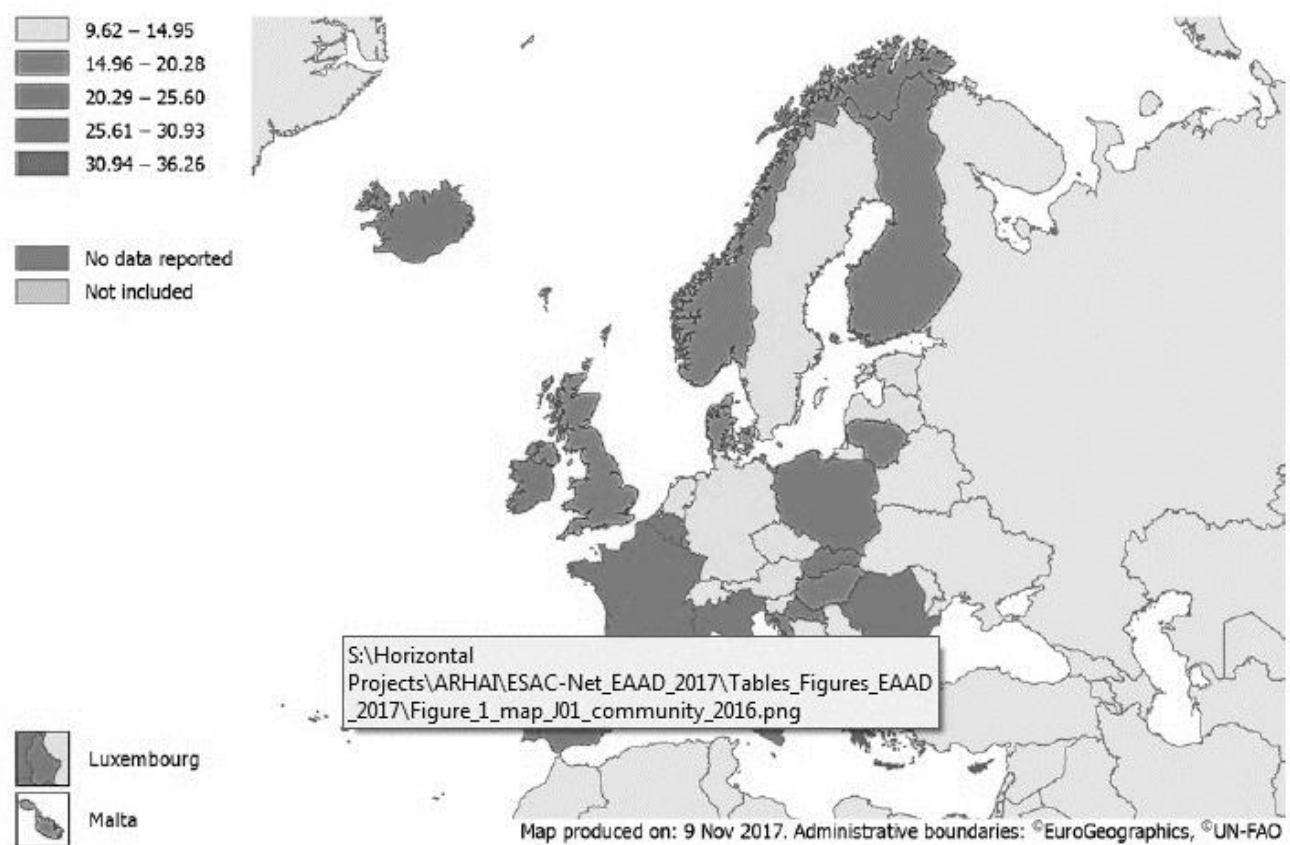

Fig. 4 Use of antibiotics for oral route of application in EU countries for 2016, DDD on 1000 citizens per day.

Макед. фарм. билт., 63 (2) 11 - 20 (2017) 


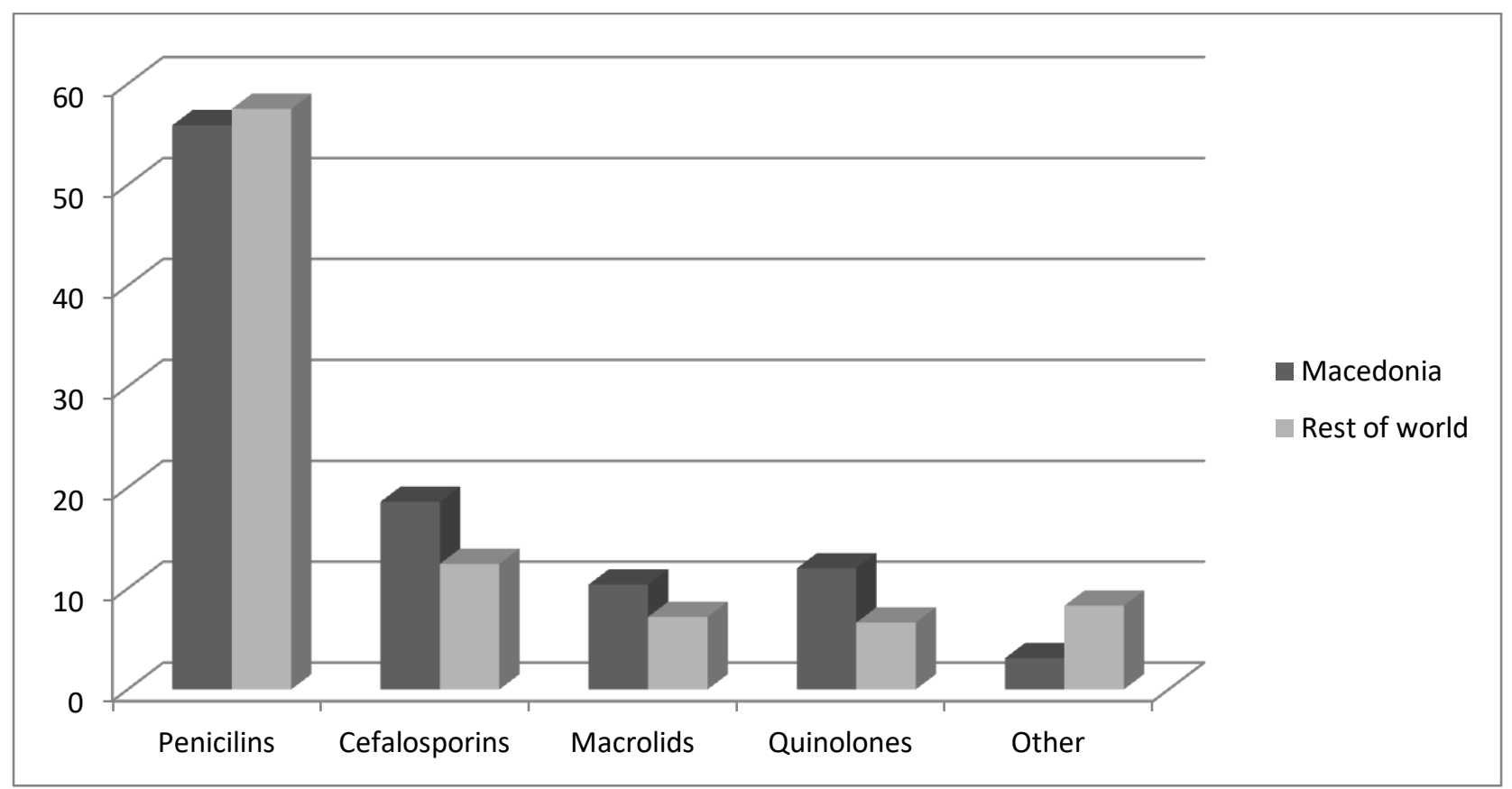

Fig. 5 Percentage of DDD of used oral antibiotics at2016, Republic of Macedonia $v s$ Rest of world.

consumption of medicines for outpatient treatment are Annual Report for Drug issued every year by the Health Insurance Fund (HIF). According to Annual Report for 2016 in Republic of Macedonia, 55.9\% of all DDD for used oral antibiotics are penicillin, $18,6 \%$ are cephalosporin, macrolide antibiotics are used $10.4 \%$ DDD, quinolones $12.0 \%$ and the rest antibiotics are $3.1 \%$ DDD`s (Fig. 5).

According to the annual report and comparison of sales, trends in sales of different classes of antibiotics in Republic of Macedonia, are almost similar to the global trend of consumption and sales of antibiotics. Penicillin's and cephalosporin's are dominant classes of sales of antibiotics in Republic of Macedonia. Quinolones are sold more than macrolides, while in the rest of the world macrolides are more used than quinolones. The biggest difference in all classes of antibiotics is in "other" group of antibiotics, where all new classes of new antibiotic medicines are included. On a global level all new antibiotic classes are widely used, but in Republic of Macedonia, only a few antibiotics are used in everyday practice in 2016.

\section{Discussion}

\section{Trends of Global Antibiotic Sales}

Globally new and expensive antibiotics, both with oral and with parenteral route of administration, are used more in developed countries (North America and Europe), while undeveloped countries (Africa, Asia, South America) mainly use old beta lactam antibiotics, penicillins and cephalosporins.

According to study of Van Boeckel et al. (2014), between 2000 and 2010, the consumption of antibiotic drugs was increased by $35 \%$ in generally. BRIC countries (Brasil, Russia, India, and China) represent $76 \%$ of the percentage increase. In most countries, antibiotic consumption varied significantly with summer/winter season variations. There is increased consumption of carbapenems (45\%) and polymixins (13\%), last-resort classes of antibiotic drugs.

The global consumption of antibiotics, expressed in dollar is shown in Fig. 4. Of all, 28.41\% cephalosporin, $27.45 \%$ penicillin occupies of total dollars spend for antibiotics for 2016, $11.5 \%$ macrolide, $16.95 \%$ quinolones, tetracycline antibiotics $3.82 \%$, aminoglycosides $2.39 \%$, trimethoprim combined antibiotics $0.7 \%$ and $8.83 \%$ for the rest antibiotics (Hamad, 2010).

\section{Trends in antimicrobial resistance (AMR)}

Antimicrobial resistance data (AMR) in Republic of Macedonia are collected none systematically, and mainly from experts microbiologists for scientific studies and projects. All previous studies are in correlation with scientific scopes and published in various journals, doctoral or master theses. Researches are related mostly to following bacteria's: Methicillin resistant Staphylococcus aureus (MRSA), Escherichia coli, ESBL positive enterobacteria, Streptococcus pneumoniae, Enterococcus, Pseudomonas aeruginosa, Acinetobacter species, Campylobacter and Helicobacter. The main reason why Republic of Macedonia is not presented on the data maps 
of European reports for AMR is because strains of resistant bacteria are not stored for confirmation. Collected data for AMR is very similar to present data from neighboring countries: Serbia, Bulgaria and Greece, which means that there is no significant differences among data for AMR in South Europe and Mediterranean countries. Still there is urgent need for further implementation of measures for AMR data system which will provide sufficient data for any further antibiotic consumption challenges (Ministry of Health of Republic of Macedonia 2011).

\section{Need of pharmacoeconomic system in health policy}

The precise and beneficial information is key factor in pharmacoeconomic analysis, when implementing pharmacoeconomic analysis in decision making process of the health care system, analysis must be complete in resolving clinical and economic issues of the problem and financing of the study must be transparent to eliminate all conflict of interest. Further well planned and organized Cost-efficacy (CEA), Cost Benefit (CBA) and CostUtility (CUA) analyses will provide plenty of information, for improved use of new and old antibiotics in Republic of Macedonia. For example, pharmacoeconomic analysis of the use of antibiotics for ambulatory treatment for acute exacerbations of chronic obstructive pulmonary disease (AECOPD) was conducted in Macedonia and published in 2016 (Acevski et al., 2016). Results from this analysis revealed truth out of some apparently contradictory results, i.e. the most expensive antibiotic showed cost-effectiveness positive performance and the least expensive antibiotic (with longest usage) had some opportunities over other analyzed antibiotics. This study gave valuable data showing the obvious need for pharmacoeconomic analysis when deciding which antibiotic treatment will give the best outcome for the patient with acute exacerbation of COPD, with less produced expense for the society and for a patient.

When conducting Cost-Effectiveness analysis (CEA) we must bear on mind that medical conditions are subject to research, both therapeutic alternatives have medical approval, by the process of evidence-based medicine, there is sufficient evidence that both alternatives will gain positive results, positive effects of the treatment will overcome adverse effects and health intervention is a most affordable methodology that could solve the health problem. Health authorities and insurance companies accept CEA for medical decision process, but medical specialists see CEA as a limitation for clinical decisions. After determining the need for medical intervention, financial structures could evaluate medical intervention as part of their sustainability management and then suggest some intervention in medical treatment. When conducting pharmacoeconomic analysis most of the medical interventions could benefit in years after the intervention, that is the reason why, when making pharmacoeconomic evaluations, 5\% annual interest should be calculated in the final result.

When making correct and accurate pharmacoeconomic analysis, the following points must be taken in consideration: analysis is made on demand and some other data, in order to evaluate which disease, patients or doctor could have most benefit from the intervention, experienced professionals trained in pharmacoeconomic analysis should guide the process in order to turn useful information into data that has value for decision making, precise software, technical equipment, and computational systems should be used to execute specific pharmacoeconomic analysis and

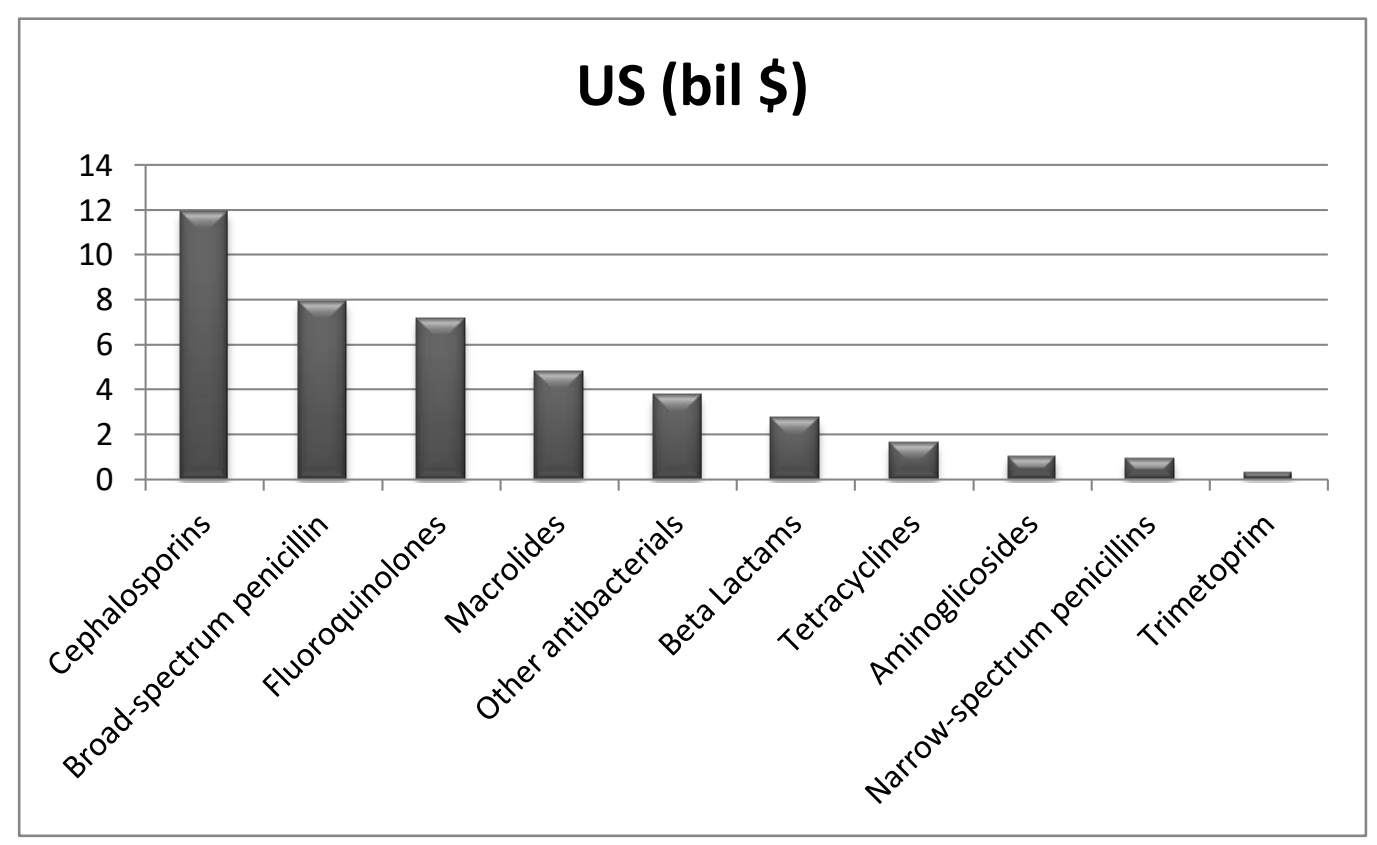

Fig. 6 Sales of antibiotics in 2016, worldwide.

Макед. фарм. билт., 63 (2) 11 - 20 (2017) 
pharmaceutical and medicinal data should be integrated.

Often insurance companies, and that is the case in Republic of Macedonia also, do not use pharmacoeconomic evaluation process, but use methodology of budgeting, pay per performance, pay on diagnostically related groups (DRG), thus shifting the cost control process to the doctor's side.

There are some restrictions in executing pharmacoeconomic analysis. Reliability of collected data, lack of comparable studies, bias in data sources, disagreements about cost measurement and benefit assessment for the patient, subjectivity about defining the cost threshold for a particular therapy could be barrier in conducting pharmacoeconomic analysis. Researchers could underestimate health benefit for the patient and could use limited prove for clinical efficacy of the medicines used in the intervention (Drummond, 1992). Another problem is the consideration of the ratio of efficacy and equality of the treatment; i.e. will the health insurance policy allocate resources equally among all members or they will focus on only a few specialized treatment programs? Some authors (Oreskovic, 2002) highlight use of anatomical therapeutic groups (ATC) and daily dose method (DDD) as common mistake when conducting pharmacoeconomic analysis. World Health Organization (WHO) has accepted DDD and ATC as a methodology for determining drug consumption, but DDD is not recommended daily dose. Different treatment areas have different DDD for treatment of some diseases, also numerous medicines do not have DDD, and there are a lot of limitations with medicines that have deviations from usual dosage regimen, same medicine could be used for different therapeutically indications (e.g. antibiotics for various therapeutic indications). Also, DDD methodology does not apply to child doses, which are relatively lower than doses for adult patients. ATC classification is good methodology but only for drug consumption, not for price calculations, cost calculations or evaluation of the efficacy of the medicines. ATC classification does not evaluate therapeutic equivalence between medicines because does not evaluate the duration of the treatment, efficacy or health consequences of the treatment (Kielhorn and Von der Schulenburg, 2000).

\section{Conclusion}

Presented results from antibiotic consumption analysis in Republic of Macedonia at 2016 showed that total antibiotic consumption and antibiotic consumption per DDD per 1000 citizens is according to average EU trends, mostly similarly to the usage trends of low-income countries. But usage of new and innovative antibiotic is on very low level, which indicates the need of further implementing of pharmacoeconomic analysis and principles in decision making process, for improved health care for the patients. With implementing pharmacoeconomic principles and methodologies clinical and economic data will be collected and connected and various projections could be made. Developed countries (EU, Canada, Australia, New Zealand etc.) have fully implemented the pharmacoeconomic principle in their health systems, thus achieving control over pharmaceutical costs while improving patient's health. Wider use of the pharmacoeconomics in decision making in the healthcare system, in each segment research and development of medicines, registration, reimbursement decision making, as well as in the process prescribing drugs or various therapeutic alternatives, will benefit for healthcare system with the ultimate goal better health to patient through improved resource allocation.

\section{References}

Acevski, S., Minov, J., Sterjev, Z., Zareski, R., Kapedanovska Nestorovska, A., Suturkova, Lj., 2016. Cost Effectiveness Analysis of Antibiotic Regimens Used inOutpatient Treatment of Exacerbation of Chronic Obstructive Pulmonary Disease (COPD). Adv. Pharmacoepidemiol. Drug Saf. 5, 212. Available at: https://doi.org/10.4172/2167-1052.1000212.

Annual Report for 2016. Health Insurance Fund of Republic of Macedonia, available at: http://www.fzo.org.mk. Last accessed: January 22, 2018.

Cairns, J., 1996. Measuring health outcomes. BMJ 313(7048), 6.

Drummond, M., 1992. Cost-of-illness studies. Pharmacoeconomics 2(1), 1-4. Available at: https://doi.org/10.1136/bmj.320.7245.1335.

Drummond, M., 1994. Economic analysis alongside controlled trials: an introduction for clinical researchers. London: Department of Health.

Drummond, M.F., Richardson, W.S., O'Brien, B.J., Levine, M., Heyland, D., 1997. Users' guides to the medical literature. XIII. How to use an article on economic analysis of clinical practice. A. Are the results of the study valid? Evidence-Based Medicine Working Group. JAMA 277(19), 1552-1557. Available at: https://doi.org/10.1001/jama.277.19.1552.

Drummond, M.F., McGuire, A. 2001. Economic evaluation in health care: merging theory with practice. OUP Oxford.

Elliott, W.J., 2003. The economic impact of hypertension. The Journal of Clinical Hypertension 5(3), 3-13. Available at: https://doi.org/10.1111/j.1524-6175.2003.02463.x.

European Centre for Disease Prevention and Control, November 2017. Summary of the latest data on antibiotic consumption in the European Union, ESAC-Net surveillance data, Stockholm.

Hamad, B., 2010. The antibiotics market. Nat. Rev. Drug Discovery 9(9), 675-676.

Hickey, A.M., Bury, G., O'Boyle, C.A., Bradley, F., O'Kelly, F.D., Shannon, W., 1996. A new short form individual quality of life measure (SEIQoL-DW): application in a cohort of individuals with HIV/AIDS. BMJ 313 (7048), 29-33. Available at: https://doi.org/10.1136/bmj.313.7048.29.

Hunink, M.G.M., Weinstein, M.C., Wittenberg, E., Drummond, 
M.F., Pliskin, J.S., Wong, J.B., Glasziou, P.P., 2014. Decision making in health and medicine: integrating evidence and values. 2nd Ed. Cambridge University Press.

Kielhorn, A., Graf von der Schulenberg, J.M., 2000. The Health Economics Handbook. 2nd Ed. Chester, Adis International.

Le Grand, A., Hegerzeil, V.H., Haaijer-Ruskamp, M.F., 1999. Intervention Research in Rational Use of Drugs: A Review. Health Policy and Planning 14(2), 89-102. Available at: https://doi.org/10.1093/heapol/14.2.89.

Ministry of Health of Republic of Macedonia March 2011. National Strategy for Containment of Antimicrobial Resistance 2012 - 2016.

Normand, C., 1991. Economics, health and the economics of health. BMJ 303(6817), 1572-1577. Available at: https://doi.org/10.1136/bmj.303.6817.1572.

Oreskovic, S., 2002. Pharmacoeconomics - Concepts, Methods and Controversies. MEDICUS 11(1), 27 - 36.

Orme, M.E., Hogue, S.L., Kennedy, L.M., Paine, A.C., Godfrey, C., 2001. Development of the health and economic consequences of smoking interactive model. Tobacco control 10(1), 55-61. Available at:

http://dx.doi.org/10.1136/tc.10.1.55.
Sassi, F., Cecchini, M., Lauer, J., Chisholm, D., 2009. Improving lifestyles, tackling obesity: the health and economic impact of prevention strategies. OECD iLibrary. ISSN: 18152015, Available at: https://doi.org/10.1787/18152015.

Tengs, T.O., Adams, M.E., Pliskin, J.S., Safran, D.G., Siegel, J.E., Weinstein, M.C., Graham, J.D., 1995. Five-hundred life-saving interventions and their cost-effectiveness. Risk Anal. 15(3), 369-390. Available at: https://doi.org/10.1111/j.1539-6924.1995.tb00330.x.

Van Boeckel, T.P., Gandra, S., Ashok, A., Caudron, Q., Grenfell, B.T., Levin, S.A., Laxminarayan, R., 2014. Global antibiotic consumption 2000 to 2010: an analysis of national pharmaceutical sales data. Lancet Infect. Dis. 14(8), 742-750. Available at: https://doi.org/10.1016/S1473-3099(14)70780-7.

WHO, Surveillance of antimicrobial use, Global surveillance of antimicrobial resistance. Available at: www.who.int (accessed 23.04.2018).

WHO, Collaborating Centre for Drug Statistics Methodology, 2018. Guidelines for ATC classification and DDD assignment, $21^{\text {st }} \mathrm{Ed}$. Available at: https://www.whocc.no. Last accessed April 23, 2018.

\title{
Потреба од имплементација на фармакоекономијата
} во здравствениот систем, приказ на анализа на употреба на антибиотици во Република Македонија во 2016 година

\author{
Стевче Ацевски ${ }^{1 *}$ и Зоран Наков ${ }^{2}$ \\ ${ }^{1}$ Алкалоид АД, бул. Александар Македонски бр. 12, 1000 Скопје, \\ Република Македонија \\ ${ }^{2}$ Ново Нордиск Фарма дооел, ул. Никола Кљусев бр. 11, 1000 Скопје, \\ Република Македонија
}

Клучни зборови: фармакоекономија, типови на фармакоекономски анализи, потрошувачка на антибиотици, Република Македонија

Фармакоекономијата е нова и модерна здравствена наука, воведена во развиените земји, која игра главна улога при креирањето на здравствените политики. Главна цел на фармакоекономските анализи е развивање на научна методологија за евалуација на трошоците и исходот од третманот, евалуација на економските параметри во однос на клиничките резултати од различни терапевтски опции. Во процесот на фармацевтски развој, фармацевтските компании ги имплементираат фармакоекономските принципи за различен маркетинг пристап и освојување на нови пазари. Новите здравствени системи побаруваат зголемени трошоци за медицинска грижа, фармацевтски производи и медицински помагала. Процесот на проценка на медицинските трошоци е напреднат, сега индиректните и скриените трошоци се неизбежен дел од евалуацијата. Здравствените власти од една страна, а фармацевтските компании од друга страна развија единствени методологии за евалуација. Со воведувањето на овие промени, традиционалниот концепт за евалуација на ефикасноста и безбедноста на медицинските помагала и фармацевтските производи е надмината, а фармакоекономијата стана основа за истражување, развој, регистрација, 
рафундирање, како и препишување и следење на животниот циклус на лековите. Резултатите од анализата на потрошувачката на антибиотици во Република Македонија, во 2016 година, покажа дека вкупната потрошувачка на антибиотици и потрошувачката според ДДД/1000 жители е во согласност со трендовите во државите од Европска Унија, најмногу слично на земјите во развој. Но, употребата на нови и иновативни антибиотици е на многу ниско ниво, што наметнува потреба од воведување на фармакоекономски анализи во процесот на носење на здравствените политики, со цел подобрување на здравствената грижа за пациентот. Крајна цел од воведувањето на фармакоекономскиот систем за секоја држава е зголемување на користта за пациентот преку подобрување на искористувањето на ресурсите. 
